\title{
Structural and in vitro functional characterization of a menthyl TRPM8 antagonist indicates species-dependent regulation
}

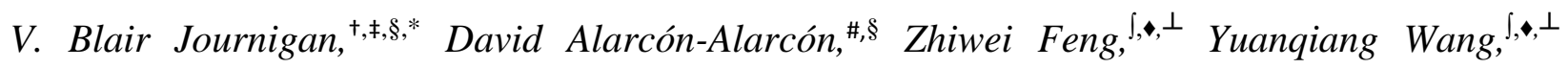
Tianjian Liang, ${ }^{\int, \bullet}{ }^{\perp}$ Denise C. Dawley,${ }^{\dagger}$ A.R.M. Ruhul Amin,${ }^{\dagger, \ddagger}$ Camila Montano, ${ }^{\|, \bullet, \Delta}$ Wade D. Van Horn $, \|, \bullet, \Delta$ Xiang-Qun Xie,,${ }^{\int, \bullet}{ }^{\perp}$ Antonio Ferrer-Montiel, ${ }^{\#}$ Asia Fernández-Carvajal ${ }^{\#}$

Table of Contents

Experimental Section

Chemistry S3-S7

Functional assays S7-S9

Molecular Modeling .S9

GC-MS traces, NMR spectra and VCD spectra

Figure S1. Comparison of gas chromatograms of the crude mixtures of oxime I-2 and amine I-3 with the corresponding mass spectrum of each major peak (labelled) $\mathrm{S} 10$

Figure S2. Gas chromatogram of (2S,5R)-2-isopropyl-5-methylcyclohexan-1-one oxime I-2 with the corresponding mass spectrum of each labelled peak

S11

Figure S3. Gas chromatogram of $(1 R, 2 S, 5 R)$-2-isopropyl-5-methylcyclohexan-1-amine $\mathbf{I}-3$ with the corresponding mass spectrum of the labelled

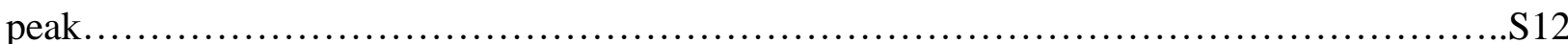

Figure S4. ${ }^{1} \mathrm{H}$ NMR spectrum of (2S,5R)-2-isopropyl-5-methylcyclohexan-1-one oxime I-2 $\ldots$ S13 
Figure S5. ${ }^{13} \mathrm{C}$ NMR spectrum of (2S,5R)-2-isopropyl-5-methylcyclohexan-1-one oxime I-

2.

S14

Figure S6. ${ }^{1} \mathrm{H}$ NMR (400 MHz) spectrum of (1R,2S,5R)-2-isopropyl-5-methylcyclohexan-1amine $\mathbf{I}-\mathbf{3}$ S 15

Figure S7. ${ }^{13} \mathrm{C}$ NMR $(75 \mathrm{MHz})$ spectrum of $(1 R, 2 S, 5 R)$-2-isopropyl-5-methylcyclohexan-1-amine

I-3. S16

Figure S8. IR (lower frame) and VCD (upper frame) spectra of (-)-menthyl 1 in $\mathrm{CDCl}_{3} ; 100$ um path-length cell with $\mathrm{BaF}_{2}$ windows; $20 \mathrm{~h}$ collection for enantiomer and solvent; instrument optimized at $1400 \mathrm{~cm}^{-1}$. Solvent subtracted IR and VCD spectra are shown. Uppermost trace is the VCD noise spectrum S17

Figure S9. Optimized geometry [B3LYP/6311Gdp] of the lowest-energy conformer of (-)menthyl 1. Conformer occupies $25 \%$ of the total population. S18

Figure S10. ${ }^{1} \mathrm{H}$ NMR (400 MHz) spectrum of N-((1R,2S,5R)-2-isopropyl-5-methylcyclohexyl)[1,1'-biphenyl]-4-carboxamide (1) S 18

Figure S11. ${ }^{13} \mathrm{C}$ NMR (75 MHz) spectrum of N-((1R,2S,5R)-2-isopropyl-5-methylcyclohexyl)[1,1'-biphenyl]-4-carboxamide (1) S19

Figure S12. ${ }^{1} \mathrm{H}$ NMR (500 MHz) spectrum of N-((1R,2S,5R)-2-isopropyl-5-methylcyclohexyl)-

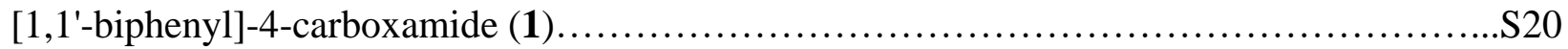

Figure S13. ${ }^{13} \mathrm{C}$ NMR (500 MHz) of $\mathrm{N}-((1 R, 2 S, 5 R)$-2-isopropyl-5-methylcyclohexyl)-[1,1'biphenyl]-4-carboxamide (1). S21

Figure S14. COSY (500 MHz) of $\mathrm{N}-((1 R, 2 S, 5 R)-2$-isopropyl-5-methylcyclohexyl)-[1,1'biphenyl]-4-carboxamide (1)... S22

Figure S15. gHSQCAD (500 MHz) of N-((1R,2S,5R)-2-isopropyl-5-methylcyclohexyl)-[1,1'biphenyl]-4-carboxamide (1). . $\mathrm{S} 23$ 
Figure S16. NOESY (500 MHz) of $\mathrm{N}-((1 R, 2 S, 5 R)-2$-isopropyl-5-methylcyclohexyl)-[1,1'-

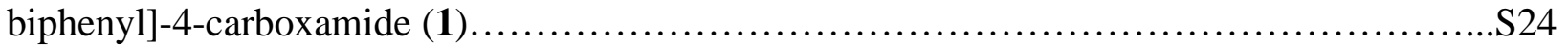

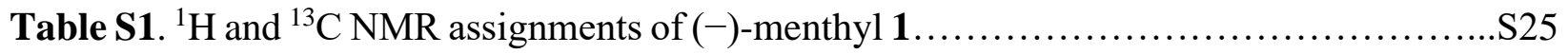

Figure S17. Key NOE interactions of (-)-menthyl 1 demonstrating relative configuration.....S26

\section{Experimental Section}

\section{Chemistry}

Thin layer chromatography was performed on Analtech silica gel GF 250 micron TLC plates. The plates were visualized by staining with iodine, p-anisaldehyde or $254 \mathrm{nM} \mathrm{UV} \mathrm{light.} \mathrm{Automated}$ flash chromatography was carried out on a Biotage Isolera Prime automated flash purification system with a multi-variable wavelength (200-400 nm) detector (Model ISO-PSV), using Biotage SNAP Ultra cartridges (10 g and $50 \mathrm{~g}$ ) packed with Biotage HP-Sphere ${ }^{\mathrm{TM}} 25$ micron spherical silica and a binary gradient, at a flow rate of 12 and $50 \mathrm{~mL} / \mathrm{min}$, respectively. Eluted peaks were monitored at 254 and $280 \mathrm{~nm}$. NMR was recorded on a Bruker Ascent $400 \mathrm{MHz}$ NMR using $\mathrm{CDCl}_{3}$. Gas Chromatography was performed on intermediates I-2 and I-3 with an Agilent 7890B gas chromatograph coupled to a 5977A mass spectrometer using a J\&W HP-5 GC column (Agilent, USA, length: $30 \mathrm{~m}$, inner diameter: $0.25 \mathrm{~mm}$, film: $0.25 \mu \mathrm{m}$, carrier gas: helium). The GC-MS was tuned the day of analysis using DFTPP/BFB to ensure that the instrument passed the quality control checks. A methanol wash vial was inserted before and after every sample as negative control. The following method was used: $50{ }^{\circ} \mathrm{C}$, rate $15{ }^{\circ} \mathrm{C} / \mathrm{min}$ up to $300{ }^{\circ} \mathrm{C}, 300{ }^{\circ} \mathrm{C}$ for $8 \mathrm{~min}$ ). The mass spectra were subjected to the NIST library. Low resolution mass spectra of intermediates I-2 and I-3 were obtained on a Thermo Scientific Q Exactive mass spectrometer (Thermo Fisher, San Jose, CA) using positive electrospray ionization (ESI) mode, via direct 
infusion. Theoretical simulated molecular mass was obtained using Thermo Xcalibur software version 4.1.31.9, and mass accuracy was calculated to be less than $10 \mathrm{ppm}$. Mass spectra for 1 was obtained on an Agilent 1290 Infinity and 6490 Triple Quad LC/MS using electrospray ionization (ESI) mode. Elemental analysis was performed by Atlantic Microlabs, Norcross, GA. IR-VCD spectra were recorded on a Chiral IR-2X instrument equipped with DualPEM (BioTools, Inc.; Jupiter, FL). Absolute configuration was determined with ComputeVOA (BioTools Inc.), employing the B3LYP method and 6311Gdp basis set in Gaussian '09 (Gaussian Inc.; Pittsburgh, PA).

(2S,5R)-2-isopropyl-5-methylcyclohexan-1-one oxime (I-2). To a stirred solution of Lmenthone I-1 (5.04 g, 32.7 mmol, 1.00 equiv) in EtOH: $\mathrm{H}_{2} \mathrm{O}(41 \mathrm{~mL}: 41 \mathrm{~mL})$ was added hydroxylamine $\mathrm{HCl}$ (6.81 g, $98.0 \mathrm{mmol}, 3.00$ equiv), followed by $\mathrm{NaOH}$ (7.84 g, $196 \mathrm{mmol}, 6.00$ equiv), and the reaction was stirred at room temperature for $24 \mathrm{~h}$. The reaction was diluted with diethyl ether and water. The layers were separated, and the aqueous solution was extracted $2 \mathrm{X}$ with ether. The combined organic layers were washed with satd. $\mathrm{NaCl}(\mathrm{aq})$, dried over $\mathrm{Na}_{2} \mathrm{SO}_{4}$, filtered and concentrated to afford $5.28 \mathrm{~g}$ of the title material as white crystals in $95 \%$ yield. ${ }^{1} \mathrm{H}$ NMR (400 MHz, $\left.\mathrm{CDCl}_{3}\right) \delta 8.71(\mathrm{~s}, 1 \mathrm{H}), 3.05-3.01(\mathrm{~m}, 1 \mathrm{H}), 2.17-2.08(\mathrm{~m}, 1 \mathrm{H}), 1.92-1.64(\mathrm{~m}, 5 \mathrm{H})$, $1.43-1.32(\mathrm{~m}, 1 \mathrm{H}), 1.19-1.10(\mathrm{~m}, 1 \mathrm{H}), 0.98(\mathrm{~d}, J=8 \mathrm{~Hz}, 3 \mathrm{H}), 0.93(\mathrm{~d}, J=8 \mathrm{~Hz}, 3 \mathrm{H}), 0.91(\mathrm{~d}, J=$ $8 \mathrm{~Hz}, 3 \mathrm{H}) .{ }^{13} \mathrm{C} \mathrm{NMR}\left(75 \mathrm{MHz}, \mathrm{CDCl}_{3}\right) \delta 161.8,49.0,33.0,32.6,32.0,27.0,26.6,21.9,21.6,19.3$. GCMS m/z 169.2 $\left[\mathrm{M}^{+}\right], 154.2\left[\mathrm{M}^{+}-\mathrm{CH}_{3}\right], 127.1\left[\mathrm{M}^{+}-\mathrm{C}_{3} \mathrm{H}_{6}\right]$. LRMS (ESI) Calcd for $\mathrm{C}_{10} \mathrm{H}_{20} \mathrm{NO}$ 170.1539; found 170.1535. Analytical data are consistent with Kulisch et al, by direct comparison of ${ }^{1} \mathrm{H}$ and ${ }^{13} \mathrm{C}$ NMR spectra. ${ }^{1}$ 
$(1 R, 2 S, 5 R)$-2-isopropyl-5-methylcyclohexan-1-amine (I-3). A 3-neck flask outfitted with a reflux condenser and $\operatorname{Ar}(\mathrm{g})$ balloon was charged with toluene (ah) $(32 \mathrm{~mL})$ followed by sodium $\left(1.36 \mathrm{~g}, 59.1 \mathrm{mmol}, 20.0\right.$ equiv). The mixture was refluxed for $15 \mathrm{~min}$ at $130^{\circ} \mathrm{C}$, forming a finely dispersed system, followed by addition of intermediate $\mathbf{I}-\mathbf{2}(500 \mathrm{mg}, 2.95 \mathrm{mmol}, 1.00$ equiv) as a solution in $3 \mathrm{~mL}$ toluene (ah). EtOH $(1.00 \mathrm{~mL})$ was added dropwise, and the reaction was refluxed for $1.5 \mathrm{hr}$. The reaction was acidified to $\mathrm{pH}=0-1$ at $0^{\circ} \mathrm{C}$ using concd $\mathrm{HCl}$ (aq) (caution!), and concentrated. The material was dissolved in diethyl ether and $\mathrm{H}_{2} \mathrm{O}$, and the $\mathrm{pH}$ was adjusted to 1112 with $20 \% \mathrm{NaOH}(\mathrm{aq})$. The layers were separated, and the aqueous solution was extracted $2 \mathrm{X}$ with ether. The combined organic layers were dried over $\mathrm{Na}_{2} \mathrm{SO}_{4}$ and concentrated to give $540 \mathrm{mg}$ of the title material as a yellow oil in quantitative yield. ${ }^{1} \mathrm{H}$ NMR (400 MHz, $\left.\mathrm{CDCl}_{3}\right) \delta 2.55-2.49$ (m, 1H), 2.14-2.07 (m, 1H), 1.84-1.79 (m, 1H), 1.71-1.65 (m, 1H), 1.62-1.57 (m, 1H), $1.40(\mathrm{br} \mathrm{s}$ 1H), $1.25(\mathrm{~s}, 2 \mathrm{H}), 0.92(\mathrm{~d}, J=8 \mathrm{~Hz}, 3 \mathrm{H}), 0.89(\mathrm{~d}, J=4 \mathrm{~Hz}, 3 \mathrm{H}), 0.86-0.82(\mathrm{~m}, 4 \mathrm{H}), 0.77$ (d, $J=8$ $\mathrm{Hz}, 3 \mathrm{H}) .{ }^{13} \mathrm{C} \mathrm{NMR}\left(75 \mathrm{MHz}, \mathrm{CDCl}_{3}\right) \delta 51.8,50.8,46.0,35.2,32.3,26.2,23.5,22.6,21.6,15.8$. TLC $\left(\mathrm{SiO}_{2}\right) \mathrm{R}_{\mathrm{f}} 0.28$ (95:5 DCM: $\mathrm{MeOH}+2$ drops $\left.\mathrm{NH}_{4} \mathrm{OH}\right)$. GCMS m/z $152.2\left[\mathrm{M}^{+}-3 \mathrm{H}\right], 138.2$ $\left[152^{+}-\mathrm{CH}_{3}\right], 124.1\left[138^{+}-\mathrm{N}\right], 110.1\left[152^{+}-\mathrm{C}_{3} \mathrm{H}_{6}\right]$. LRMS (ESI) Calcd for $\mathrm{C}_{10} \mathrm{H}_{22} \mathrm{~N}$ 156.1747; found 156.1741. Analytical data are consistent with Kulisch et al, by direct comparison of the ${ }^{1} \mathrm{H}$ and ${ }^{13} \mathrm{C}$ NMR spectra. ${ }^{1}$

$\mathrm{N}-((1 R, 2 S, 5 R)-2$-isopropyl-5-methylcyclohexyl)-[1,1'-biphenyl]-4-carboxamide $\quad(1)$. To a stirred solution of [1,1'-biphenyl]-4-carboxylic acid (205 mg, $1.03 \mathrm{mmol}, 1.50$ equiv) in THF (6.80 $\mathrm{mL}$ ) was added EDCI (206 mg, $1.07 \mathrm{mmol}, 1.56$ equiv), HOBt (165 mg, $1.07 \mathrm{mmol}, 1.56$ equiv) and $\mathrm{Et}_{3} \mathrm{~N}(0.32 \mathrm{~mL}, 2.27 \mathrm{mmol}, 3.30$ equiv), and the reaction was stirred at room temperature for $1 \mathrm{~h}$. To this mixture was added a solution of intermediate $\mathbf{I - 3}(107 \mathrm{mg}, 0.689 \mathrm{mmol}, 1.00$ equiv) in 
THF, and the reaction was stirred at $40^{\circ} \mathrm{C}$ for $2 \mathrm{hr}$. The reaction was diluted with EtOAc and $\mathrm{H}_{2} \mathrm{O}$. The layers were separated, and the aqueous solution was extracted $2 \mathrm{X}$ with EtOAc. The combined organic layers were washed with satd. $\mathrm{NaCl}(\mathrm{aq})$, dried over $\mathrm{Na}_{2} \mathrm{SO}_{4}$, filtered and concentrated. The reaction was repeated on a $340 \mathrm{mg}$ scale, and the crude residue of the two runs was combined. The residue was purified $2 \mathrm{X}$ by automated flash chromatography using dichloromethane/diethyl ether $(0 / 100 \rightarrow 98 / 2)$ to afford $738 \mathrm{mg}$ of the title material in $76 \%$ yield. ${ }^{1} \mathrm{H}$ NMR $\left(400 \mathrm{MHz}, \mathrm{CDCl}_{3}\right) \delta$ 7.85-7.82 (2H, m), 7.66-7.59 (4H, m), 7.49-7.35 (3H, m), $5.87(1 \mathrm{H}$, app d, $J=12 \mathrm{~Hz}), 4.03$ (qd, $J$ $=11.0,4.0 \mathrm{~Hz}, 1 \mathrm{H}), 2.13-2.08(1 \mathrm{H}, \mathrm{m}), 2.04-1.95(1 \mathrm{H}, \mathrm{m}), 1.78-1.65(2 \mathrm{H}, \mathrm{m}), 1.55(1 \mathrm{H}, \mathrm{br} \mathrm{s})$, 1.26-1.14 (2H, m), 0.98-0.85 (11 H, m). ${ }^{13} \mathrm{C}$ NMR $\left(75 \mathrm{MHz}, \mathrm{CDCl}_{3}\right) \delta 166.4,144.1,140.1,133.8$ 128.9, 127.9, 127.4, 127.2, 50.5, 48.5, 43.2, 34.6, 31.9, 27.0, 23.9, 22.2, 21.2, 16.3. MS (ESI) $\mathrm{m} / \mathrm{z}$ $336.30(\mathrm{M}+\mathrm{H})^{+}$. Anal. Calcd. For $\mathrm{C}_{23} \mathrm{H}_{29} \mathrm{NO}$ : C, 82.34; H, 8.71; N, 4.18; found: C, 82.34; H, 8.69; N, 4.24 .

VCD Measurements of 1 . To a vial containing $13 \mathrm{mg}$ of Compound $\mathbf{1}$ was added $250 \mathrm{uL} \mathrm{CDCl} \mathrm{CD}_{3}$, this solution was transferred to a 100 um path length $\mathrm{BaF}_{2}$ IR cell. IR and VCD were measured simultaneously in a BioTools ChiralIR with DualPEM VCD spectrometer for 20 hours at spectral resolution of $4 \mathrm{~cm}^{-1}$ and PEM focus frequency of $1400 \mathrm{~cm}^{-1}$. A solvent measurement performed for 20 hours was used to correct both the IR and VCD of Compound $\mathbf{1 .}$

${ }^{1} \mathrm{H},{ }^{13} \mathrm{C}, \mathrm{g} C O S Y, N O E S Y$, and $g H S Q C A D$ of 1 . All experiments were run on a Varian Inova 500 MHz spectrometer equipped with $5 \mathrm{~mm}$ PFG broadband probe running at $499.74 \mathrm{MHz}$ and 125.67 $\mathrm{MHz}$ for ${ }^{1} \mathrm{H}$ and ${ }^{13} \mathrm{C}$ resonance frequencies, respectively. Experiments were run at ambient temperature using $\mathrm{CDCl}_{3}$ as the solvent. ${ }^{1} \mathrm{H}$ spectra were referenced against residual protonated 
solvent (7.26 ppm) and ${ }^{13} \mathrm{C}$ to $77 \mathrm{ppm}$. Spectra were processed using MestReNova (12.0.3) NMR processing program.

${ }^{1}$ H NMR: 10 second relaxation delay, $7996 \mathrm{~Hz}$ spectral window, 2.04 second acquisition time, 16 scans. Baseline correction applied using Whittaker smoother (automatic detection).

${ }^{13} \mathrm{C}$ NMR: Broadband ${ }^{1} \mathrm{H}$-decoupled, 1 second relaxation delay, 512 scans, $31409.5 \mathrm{~Hz}$ spectral window, 1.05 second acquisition time. Baseline correction applied using Whittaker smoother (automatic detection) and $0.5 \mathrm{~Hz}$ exponential multiplication was applied.

gCOSY: 1 second relaxation delay, 4 scans per increment, 128 increments, $4753 \mathrm{~Hz}$ spectral window, 0.15 second acquisition time. F1 and F2 were multiplied by Sine Square II function (50\%), as implemented by MestReNova, prior to Fourier transform. Linear prediction (Zhu-Bax) to 1024 points in F1 was applied. Baseline correction was applied to both dimensions using Whittaker smoother (automatic detection).

gHSQCAD: 1 second relaxation delay, 4 scans per increment, 200 increments; 7996, $25134 \mathrm{~Hz}$ spectral window $\left({ }^{1} \mathrm{H}\right.$, and ${ }^{13} \mathrm{C}$, respectively), 0.15 second acquisition time. $\mathrm{F} 1$ and $\mathrm{F} 2$ were multiplied by a Gaussian prior to Fourier transform. Baseline correction was applied to both dimensions using Whittaker smoother (automatic detection). Linear prediction (Zhu-Bax) to 2048 points in F1 was applied.

NOESY: 1 second relaxation delay, 16 scans per increment, 200 increments; $4753 \mathrm{~Hz}$ spectral window, 400 ms mixing time, 0.15 second acquisition time. F1 and F2 were multiplied by a Gaussian prior to Fourier transform. Baseline correction was applied to both dimensions using Whittaker smoother (automatic detection). Linear prediction (Zhu-Bax) to 2048 points in F1 was applied. 


\section{Functional assays}

$\underline{\text { Calcium imaging assays. }}$

HEK-293 cells stably transfected with rTRPM8 or hTRPM8 were seeded on coverslips at a cell density of 30.000 cells/coverslip 24 hours before the assay. One hour before the experiment, the cells were loaded with $5 \mu \mathrm{M}$ fluo-4- acetoxymethyl ester plus $0.02 \%$ pluronic acid (Molecular Probes, Invitrogen) in HBSS extracellular solution (in $\mathrm{mM}$ ): $140 \mathrm{NaCl}, 4 \mathrm{KCl}, 1 \mathrm{MgCl}_{2}, 1.8 \mathrm{CaCl}_{2}$, 5 D-glucose, and 10 HEPES, pH 7.4 for $1 \mathrm{~h}\left(37^{\circ} \mathrm{C}, 5 \% \mathrm{CO}_{2}\right)$. Coverslips were mounted in a RC25 chamber (Harvard Apparatus) and continuously perfused with test solutions at room temperature (RT).

Fluorescence from individual cells was monitored through a 10x air objective (Axiovert 200 inverted microscope, Carl Zeiss) with an ORCA-FLASH4.0 LT+ camera (Hamamatsu Photonics). Fluo-4AM excited at $500 \mathrm{~nm}$ and emitted fluorescence filtered at $535 \mathrm{~nm}$ (Lambda-10-2-filter wheel, Sutter Instruments). Images processed with HCImage DIA package software (Hamamatsu Photonics). Pre-programed protocols were applied via computer-controlled pinch valves (Bioscience Tools, $5 \mathrm{~mL} / \mathrm{min}$ flux). TRPM8 channel activity was evoked with $30 \mathrm{~s}$-application of menthol or icilin at different concentrations from $10 \mathrm{mM}$ to $1 \mathrm{nM}$. Antagonist experiments were performed by co-application of the TRPM8 agonist, menthol at $100 \mu \mathrm{M}$ or icilin at $0.5 \mu \mathrm{M}$, plus the antagonist compound $\mathbf{1}$, concentrations ranging from $1 \mathrm{mM}$ to $1 \mathrm{nM}$ or AMTB $10 \mu \mathrm{M}$ as antagonist control.

\section{$\underline{\text { Data Analysis }}$}

Intracellular $\mathrm{Ca}^{2+}$ increase was calculated as fluorescence difference between baseline and the peak reached. Size of the peak elicited by TRPM8 stimuli was normalized to responses elicited by 
ionomicin $10 \mu \mathrm{M}$. All data are expressed as mean \pm SEM. Each condition was assessed by triplicate $(\mathrm{n}=3)$ in 3 independent experiments $(\mathrm{N}=3)$.

To calculate $\mathrm{IC}_{50}$, normalized responses $(\%)$ versus $\log [\mu \mathrm{M}]$ were adjusted to a non-linear fit with variable slope, a four-parameter dose-response curve following curve $\mathrm{Y}=100 /\left(1+10^{\wedge}\left(\left(\log \mathrm{IC}_{50^{-}}\right.\right.\right.$ $\mathrm{X})^{*}$ HillSlope)) where $\mathrm{X}=\%$ normalized response and $\mathrm{Y}=\log [\mu \mathrm{M}]$.

Statistical analysis performed was two-way repeated measurements ANOVA, followed by Bonferroni's multiple comparison test. Statistical significance was usually considered $* * * * \mathrm{p}<0.0001 ; * * * \mathrm{p}<0.001 ; * * \mathrm{p}<0.01$

Whole-cell patch-clamp electrophysiology: HEK293 cells were transfected with pIRES2 human TRPM8 plasmid as described previously. ${ }^{2}$ Electrophysiology measurements were performed following established protocols with data recorded from three separate transfections on different days. ${ }^{3}$ Briefly, HEK 293 cells were plated on glass coverslips and placed in a recording chamber. The extracellular solution contained $132 \mathrm{mM} \mathrm{NaCl}, 5 \mathrm{mM} \mathrm{KCl}, 1 \mathrm{mM} \mathrm{MgCl} 2,2 \mathrm{mM} \mathrm{CaCl}_{2}, 10$ mM HEPES, and $5 \mathrm{mM}$ glucose at $\mathrm{pH}$ 7.4. The $\mathrm{pH}$ was adjusted using $\mathrm{NaOH}$ and osmolality was adjusted to $310 \mathrm{mOsm}$ using sucrose as measured using a Vapro 5600 vapor pressure osmometer (Wescor). The pipette solution contained $135 \mathrm{mM} \mathrm{K}+$ gluconate, $5 \mathrm{mM} \mathrm{KCl}, 1 \mathrm{mM} \mathrm{MgCl} 2,5 \mathrm{mM}$ EGTA, and $10 \mathrm{mM}$ HEPES, at $\mathrm{pH}$ 7.2. The $\mathrm{pH}$ was adjusted with $\mathrm{KOH}$ and osmolality adjusted to 300 mOsm using sucrose. The recording temperature was set to $24{ }^{\circ} \mathrm{C} \pm 1{ }^{\circ} \mathrm{C}$. The vector to add compound [1] was diluted from a DMSO stock solution. The resulting $\mathbf{1}$ inhibition data against $500 \mu \mathrm{M}$ menthol were fit to a single site competition model as described for our previous studies of TRPM8 antagonism. ${ }^{4}$

\section{Molecular Modeling}

Homology Modeling of rTRPM8. 
We built the rat TRPM8 homology model based on cryo-EM structure of the collared flycatcher Ficedula albicollis (PDB 6BPQ, resolution 4.1 $\mathrm{A}$ ), ${ }^{5}$ which shares $80 \%$ sequence identity to TRPM8 $8_{\text {rat. }}$ The full sequence of TRPM8 $8_{\text {rat }}$ was retrieved from the UniProt (http://www.uniprot.org/uniprot/). We used Swiss-model (https://swissmodel.expasy.org/) to complete the homology modeling process and generate the rTRPM8 structure, using a similar protocol and parameters as we previously reported. ${ }^{4}$

\section{GC-MS traces, NMR spectra and VCD spectra}

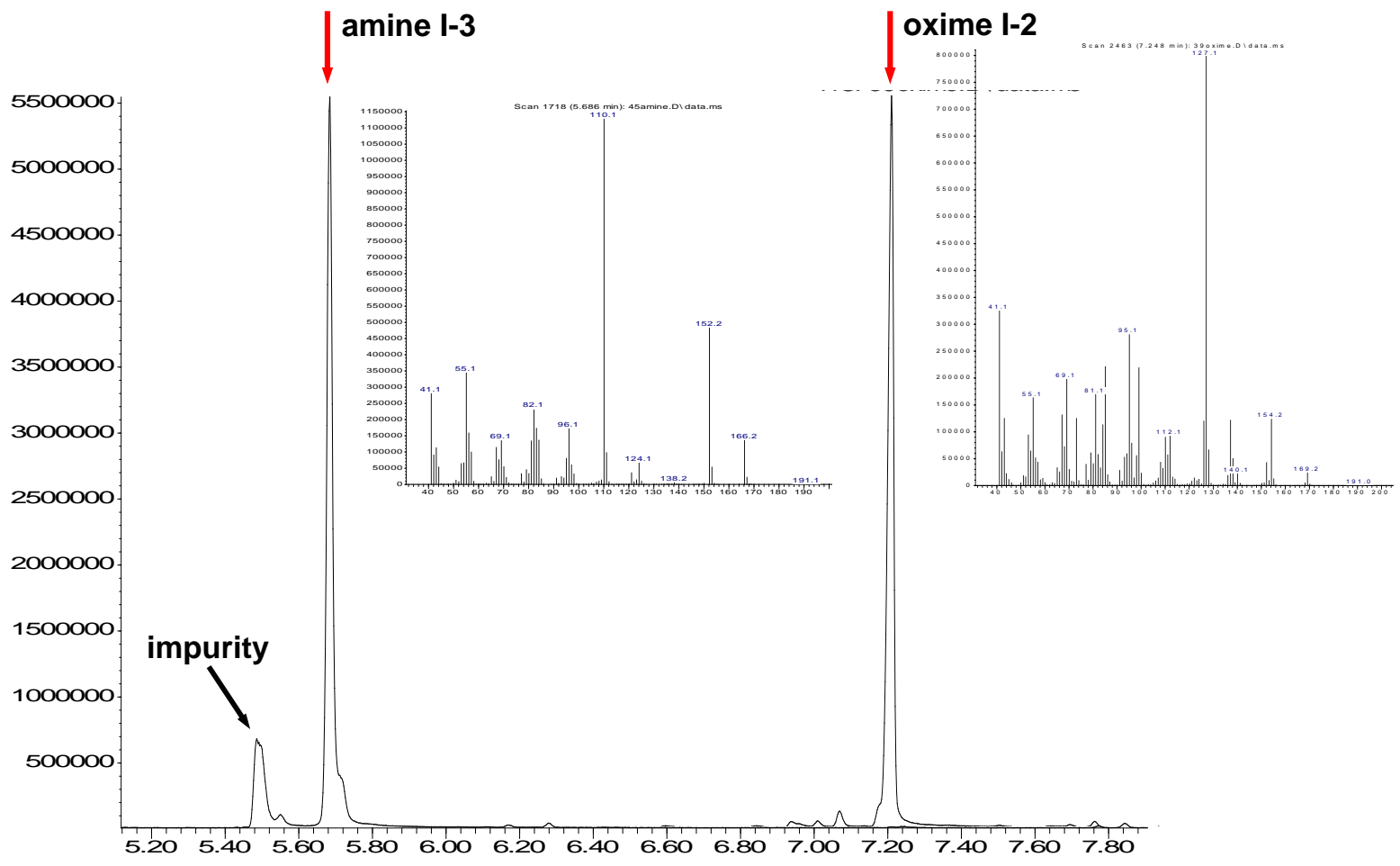

Figure S1. Comparison of gas chromatograms of the crude mixtures of oxime I-2 and amine I-3 with the corresponding mass spectrum of each major peak (labelled). 


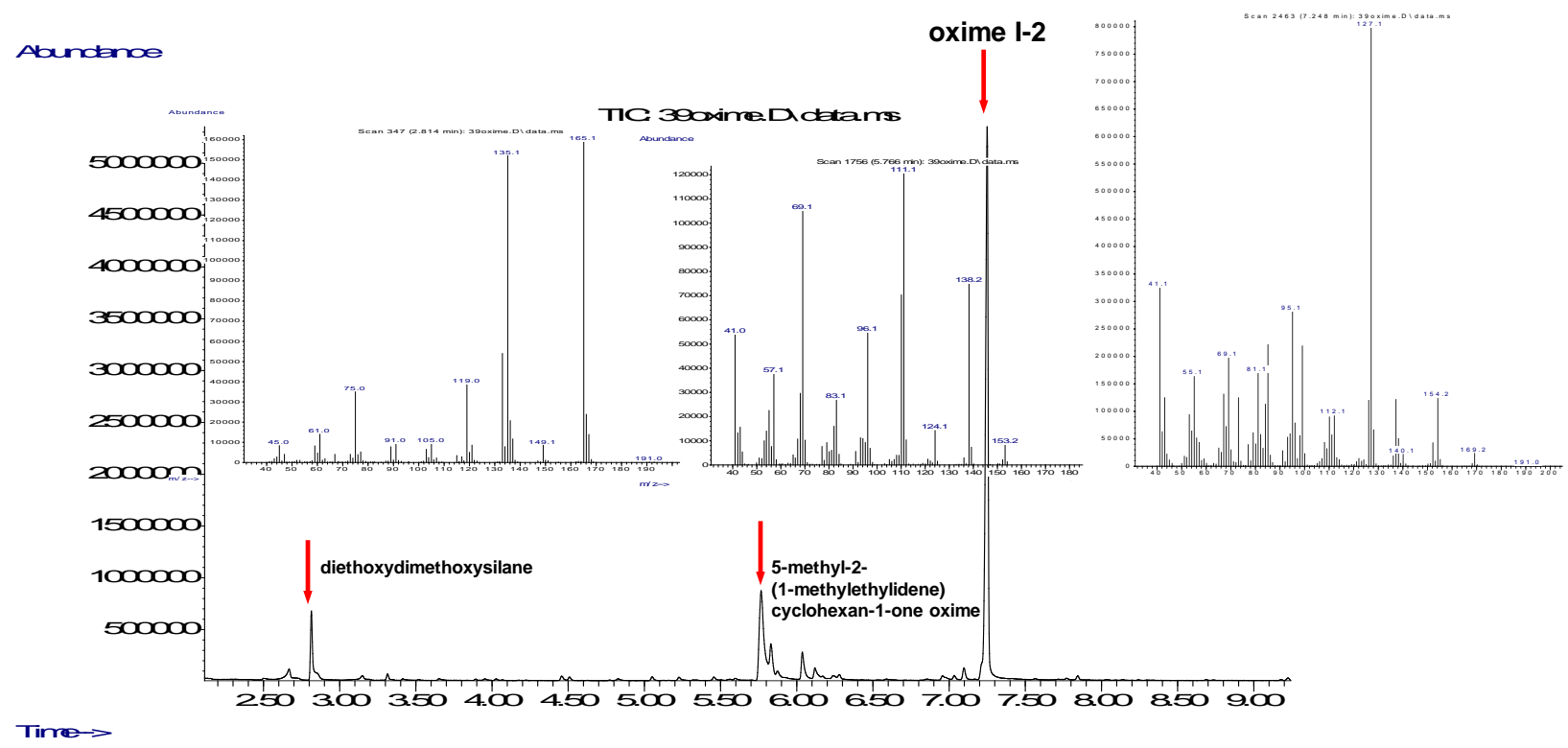

Figure S2. Gas chromatogram of (2S,5R)-2-isopropyl-5-methylcyclohexan-1-one oxime I-2 with the corresponding mass spectrum of each labelled peak. 


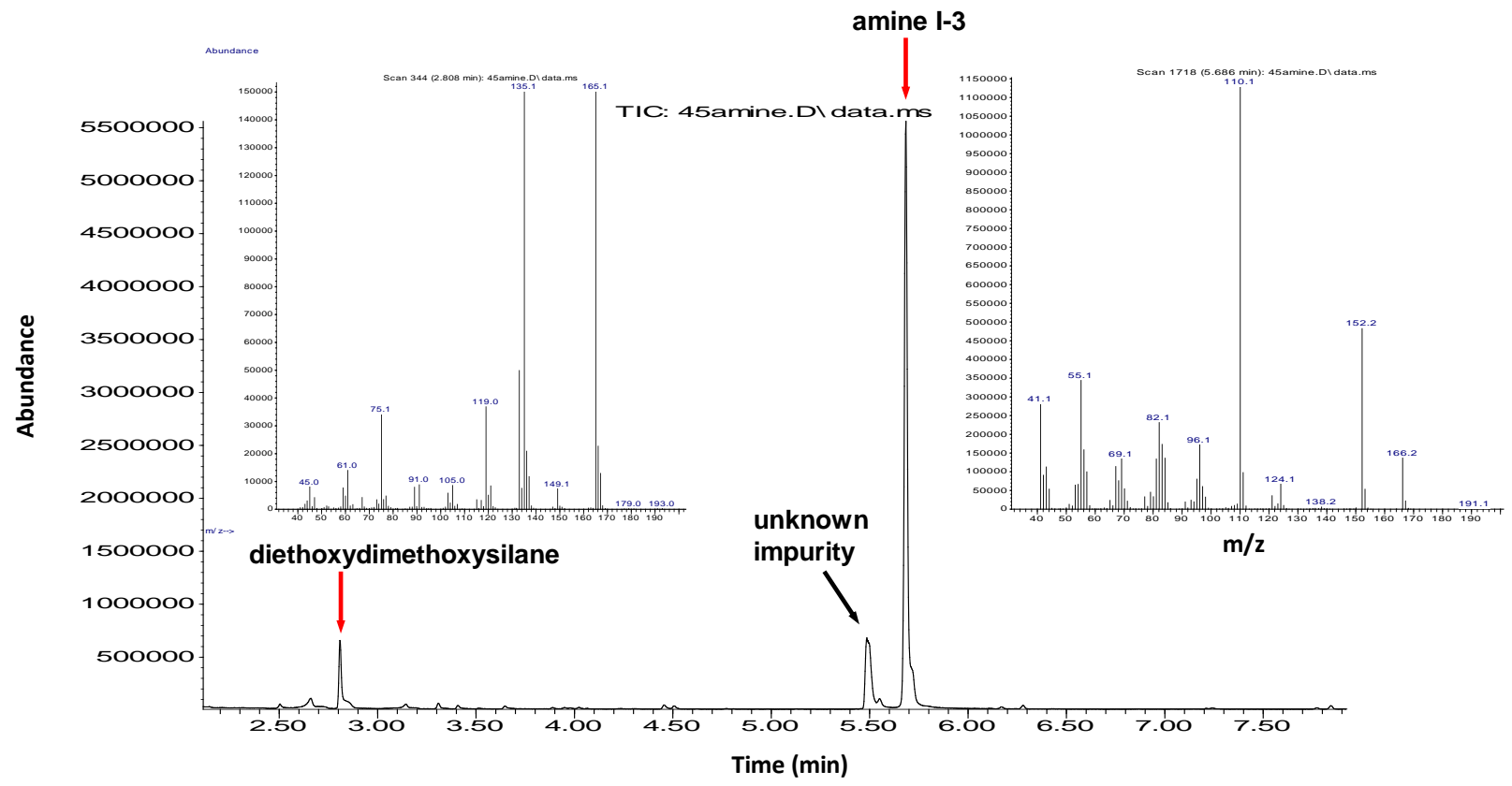

Figure S3. Gas chromatogram of $(1 R, 2 S, 5 R)$-2-isopropyl-5-methylcyclohexan-1-amine I-3 with the corresponding mass spectrum of the labelled peak. 


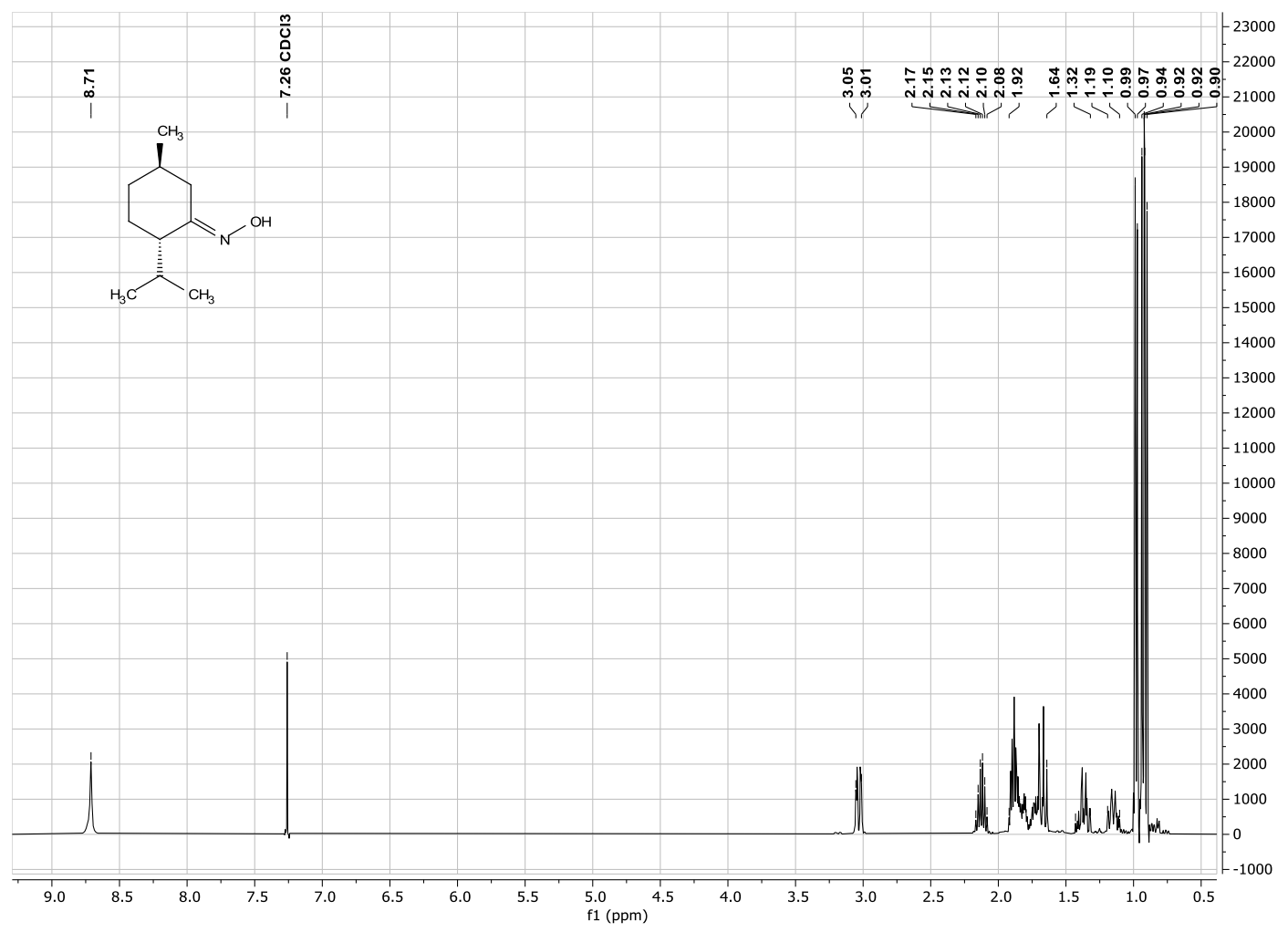

Figure S4. ${ }^{1} \mathrm{H}$ NMR spectrum (400 MHz) of (2S,5R)-2-isopropyl-5-methylcyclohexan-1-one oxime I-2. 


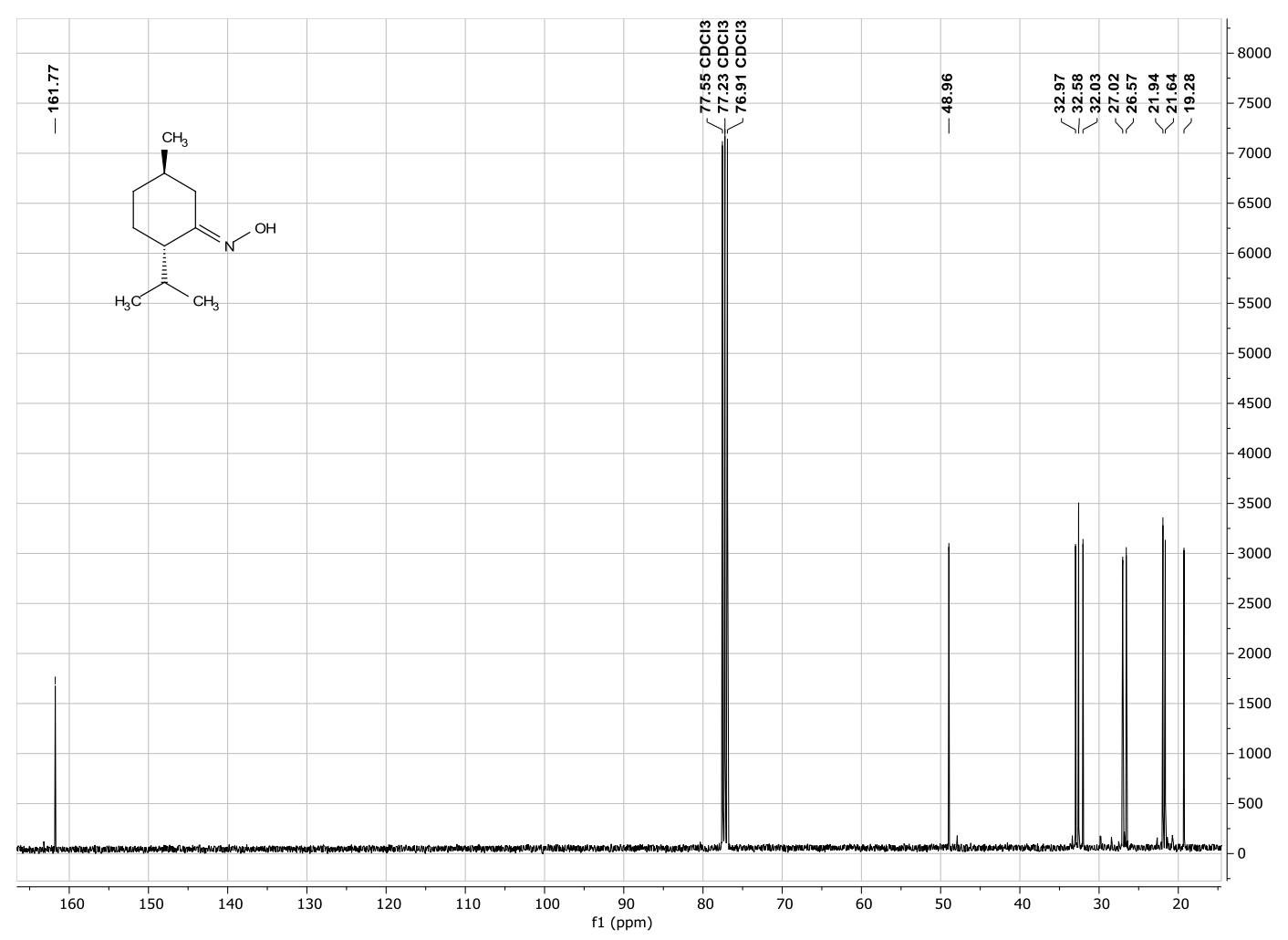

Figure S5. ${ }^{13} \mathrm{C}$ NMR (75 MHz) spectrum of (2S,5R)-2-isopropyl-5-methylcyclohexan-1-one oxime I-2. 


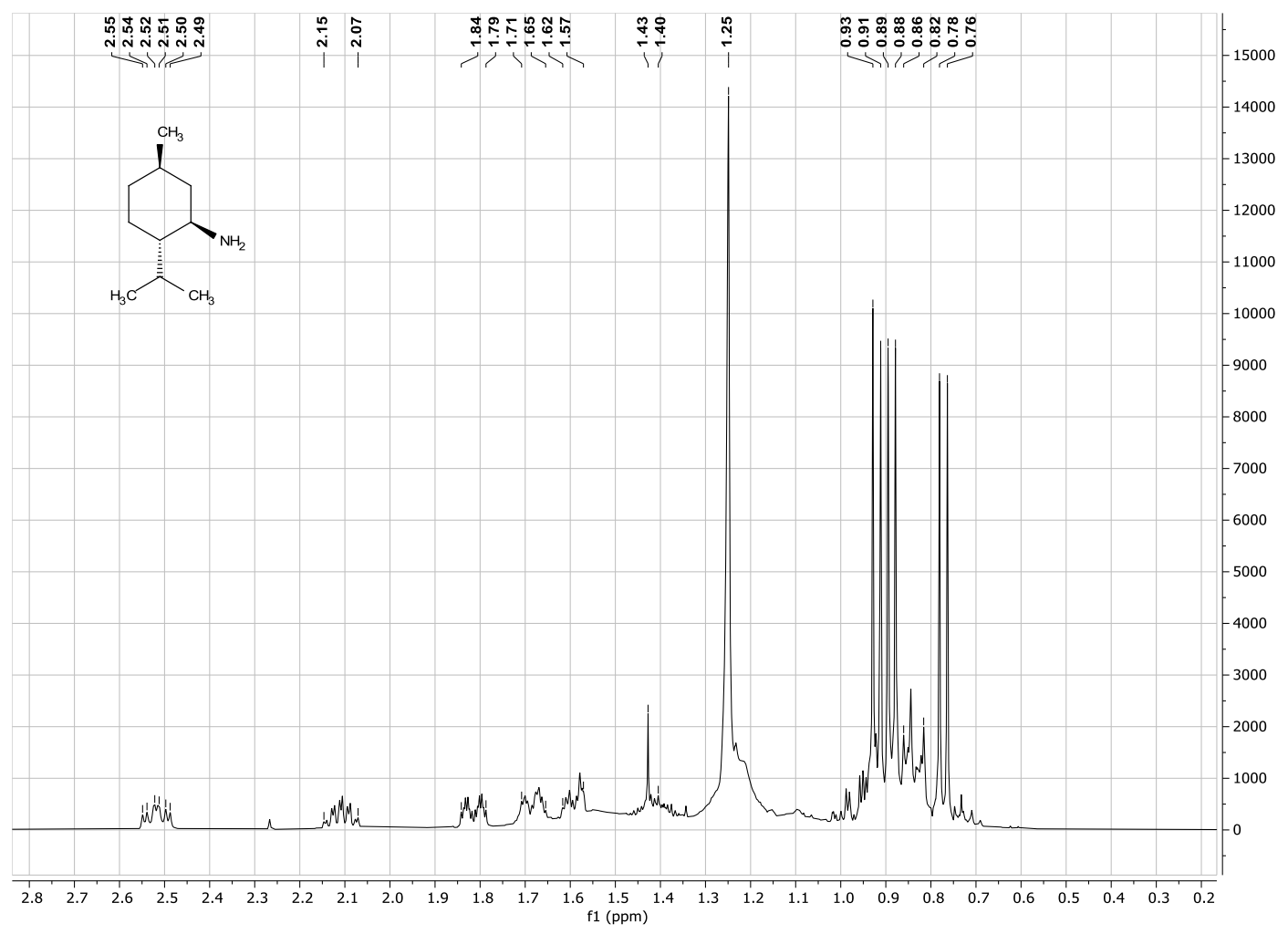

Figure S6. ${ }^{1} \mathrm{H}$ NMR $(400 \mathrm{MHz})$ spectrum of $(1 R, 2 S, 5 R)$-2-isopropyl-5-methylcyclohexan-1amine I-3. 


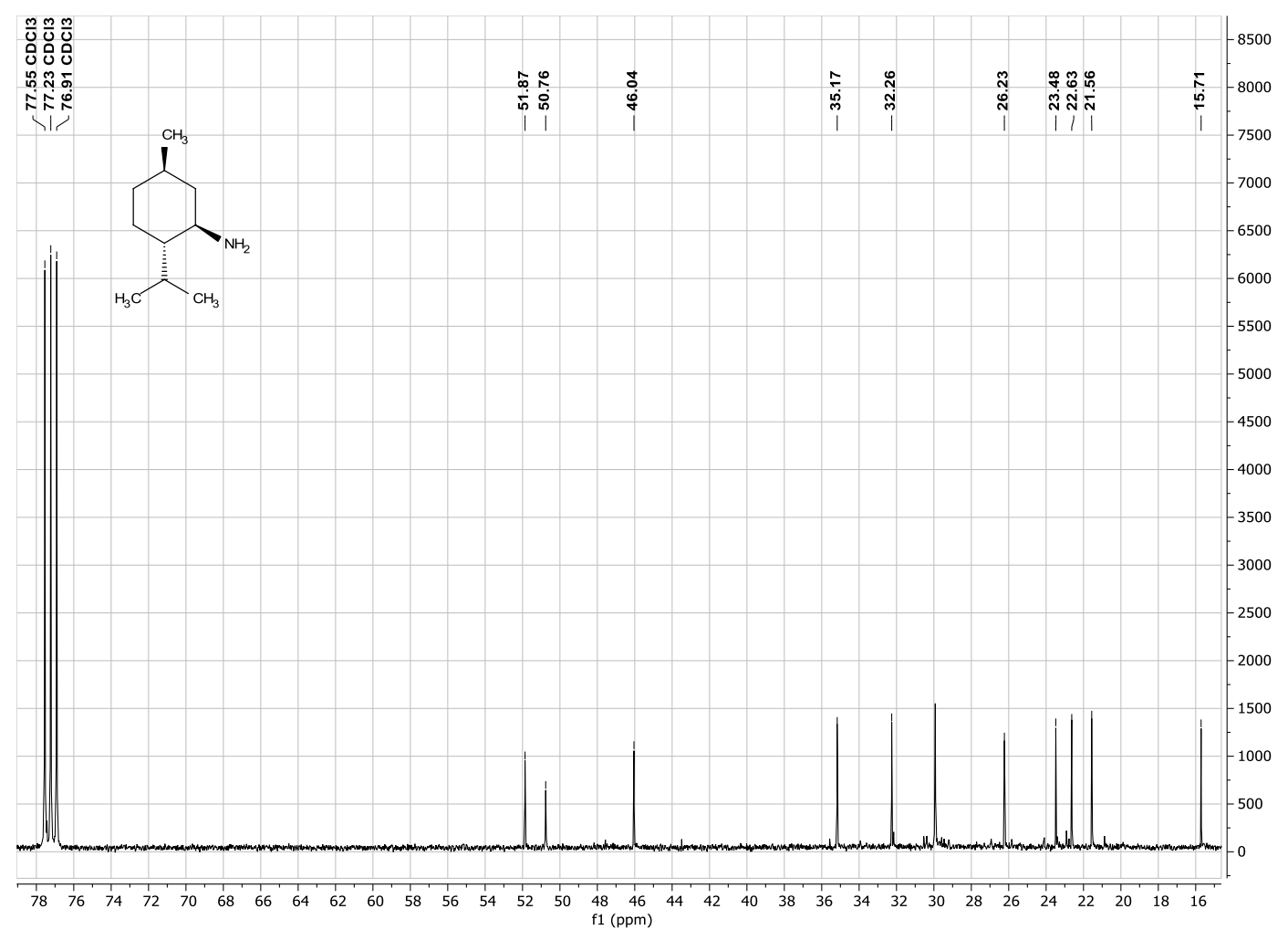

Figure S7. ${ }^{13} \mathrm{C}$ NMR $(75 \mathrm{MHz})$ spectrum of $(1 R, 2 S, 5 R)$-2-isopropyl-5-methylcyclohexan-1-amine I-3. 


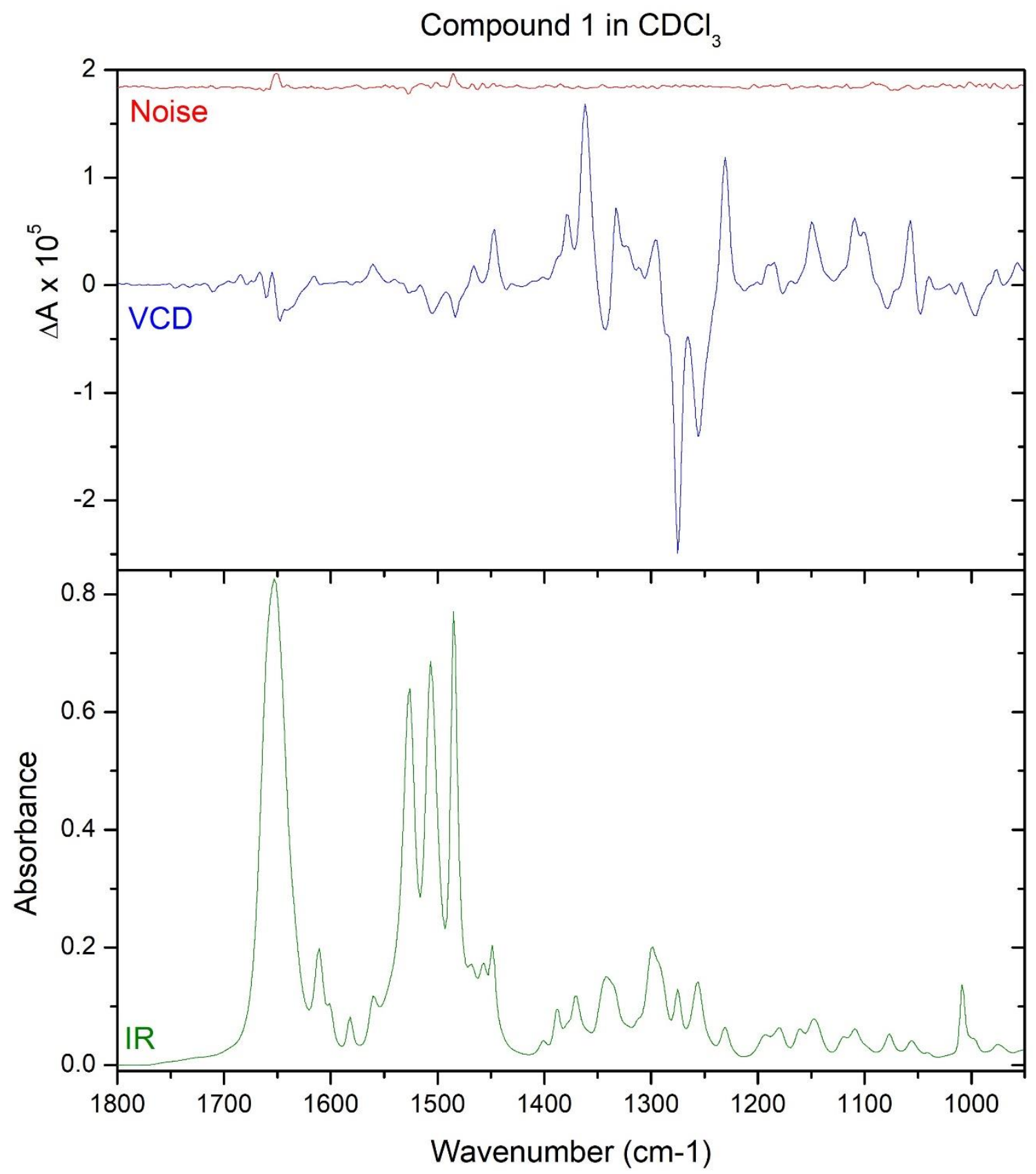

Figure S8. IR (lower frame) and VCD (upper frame) spectra of (-)-menthyl 1 in $\mathrm{CDCl}_{3} ; 100 \mathrm{um}$ path-length cell with $\mathrm{BaF}_{2}$ windows; $20 \mathrm{~h}$ collection for enantiomer and solvent; instrument optimized at $1400 \mathrm{~cm}^{-1}$. Solvent subtracted IR and VCD spectra are shown. Uppermost trace is the VCD noise spectrum. 


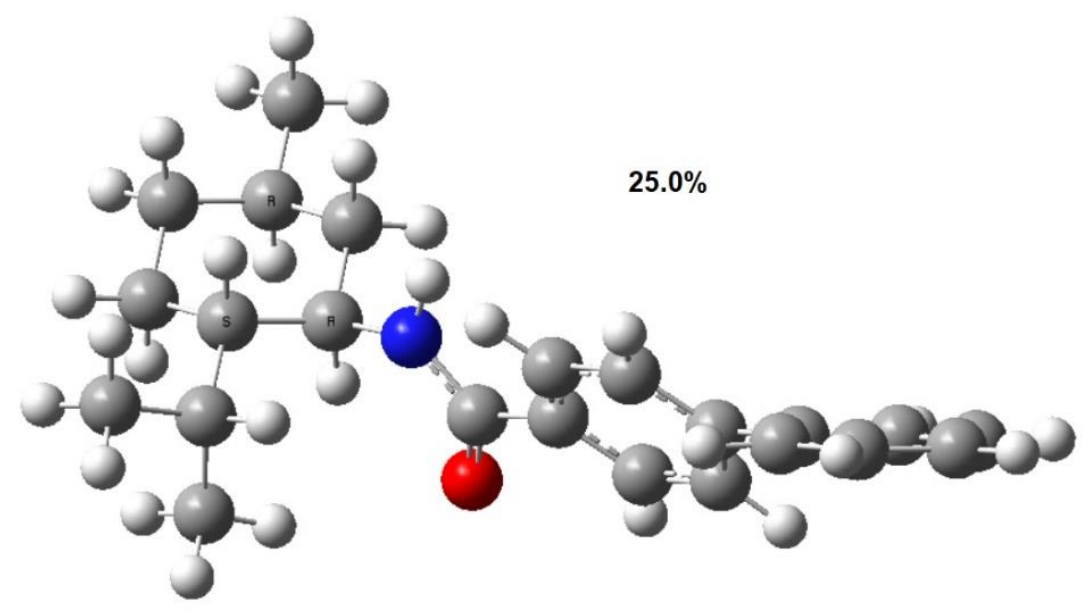

Figure S9. Optimized geometry [B3LYP/6311Gdp] of the lowest-energy conformer of (-)menthyl 1. Conformer occupies $25 \%$ of the total population.

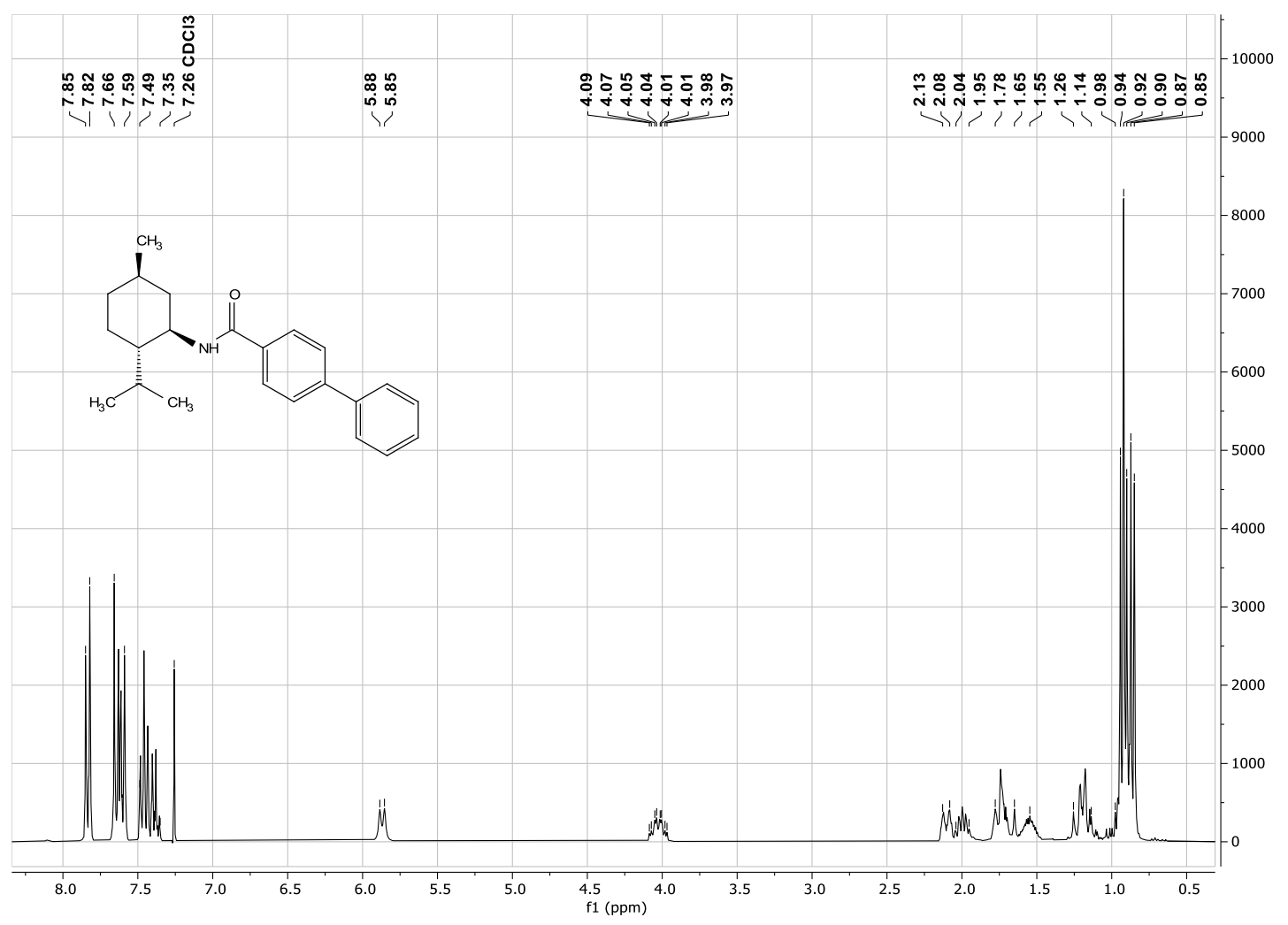

Figure S10. ${ }^{1} \mathrm{H}$ NMR (400 MHz) spectrum of N-((1R,2S,5R)-2-isopropyl-5-methylcyclohexyl)[1,1'-biphenyl]-4-carboxamide (1). 


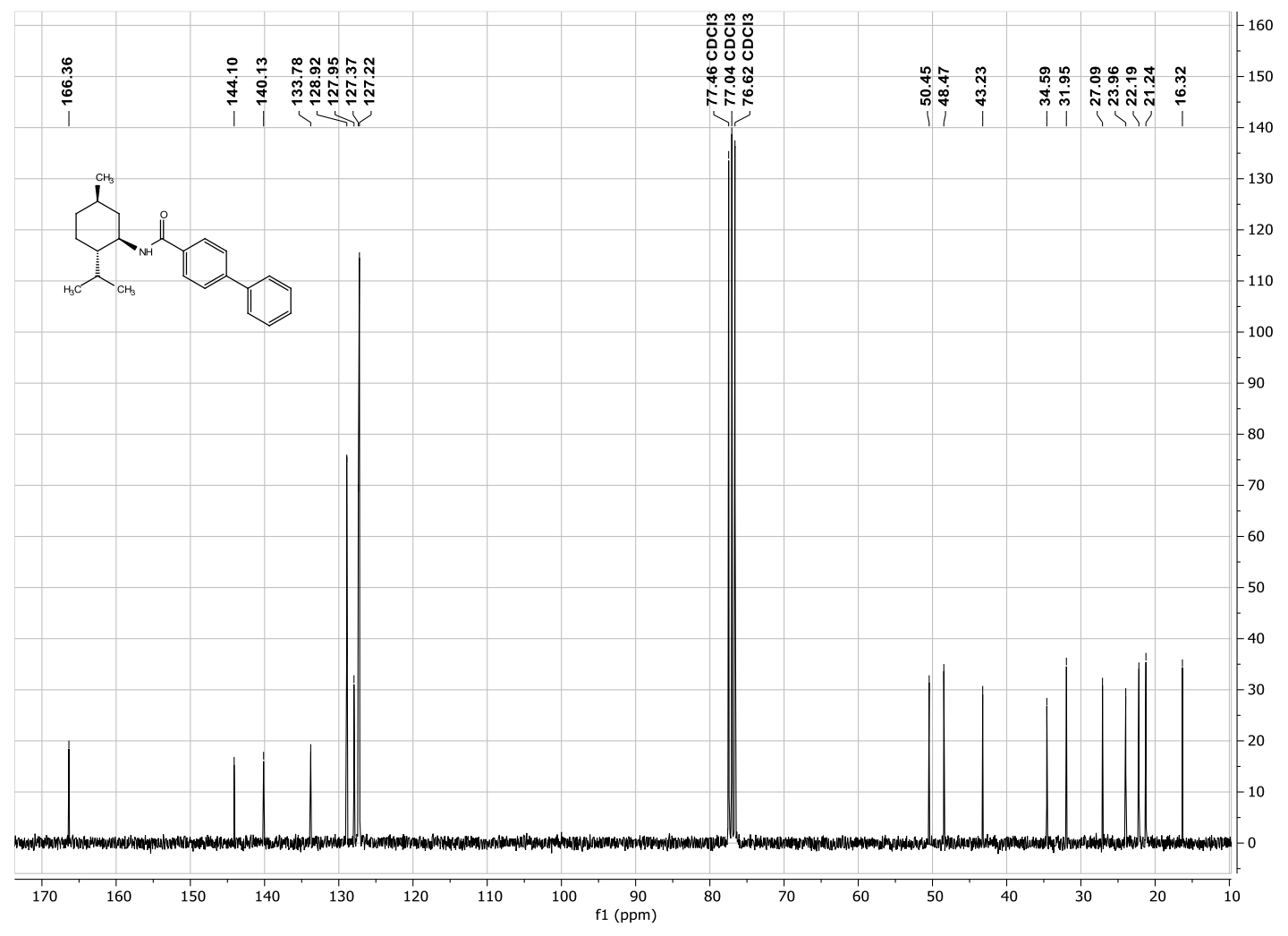

Figure S11. ${ }^{13} \mathrm{C}$ NMR (75 MHz) spectrum of N-((1R,2S,5R)-2-isopropyl-5-methylcyclohexyl)[1,1'-biphenyl]-4-carboxamide (1). 


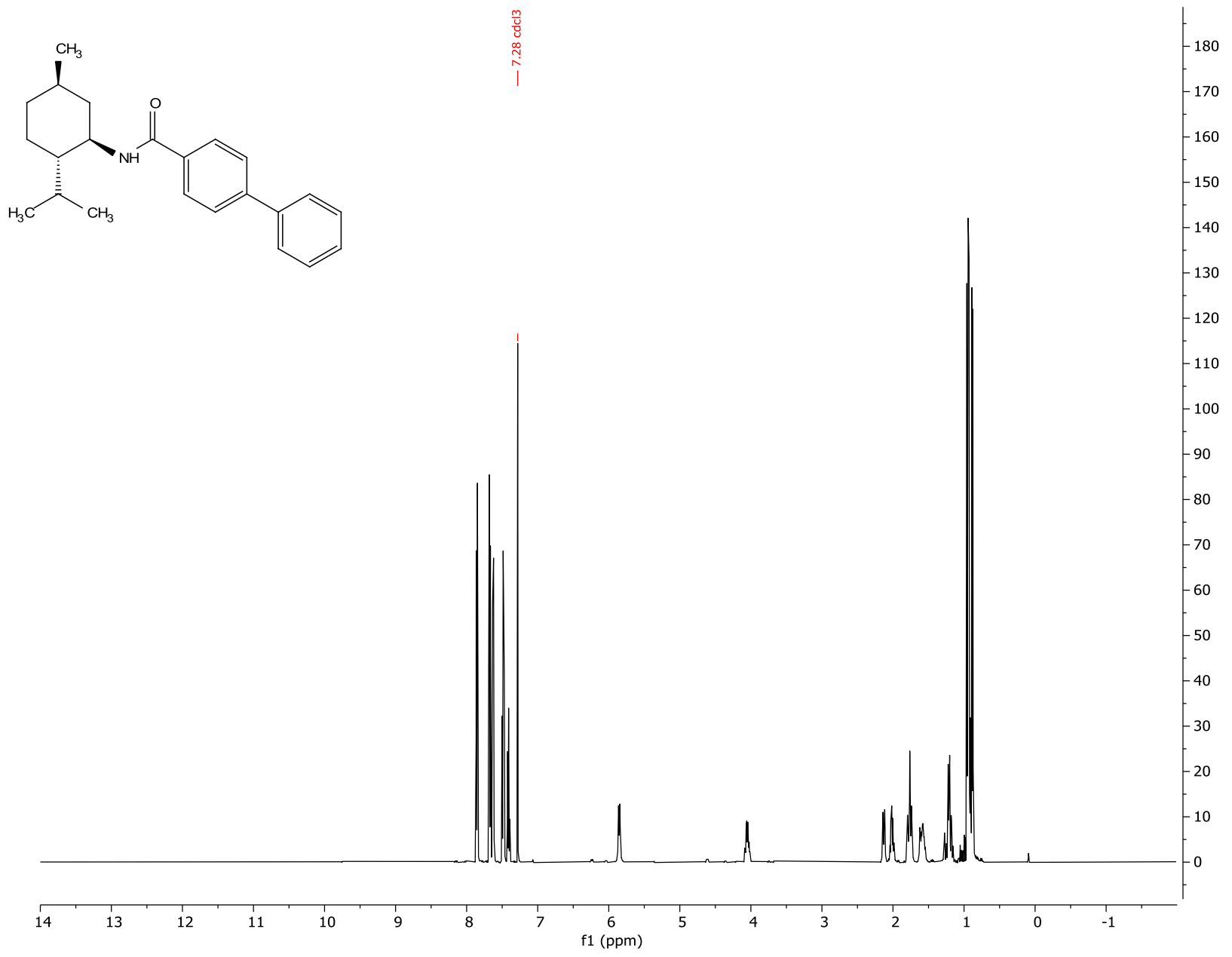

Figure S12. ${ }^{1} \mathrm{H}$ NMR (500 MHz) spectrum of $\mathrm{N}-((1 R, 2 S, 5 R)$-2-isopropyl-5-methylcyclohexyl)[1,1'-biphenyl]-4-carboxamide (1). 


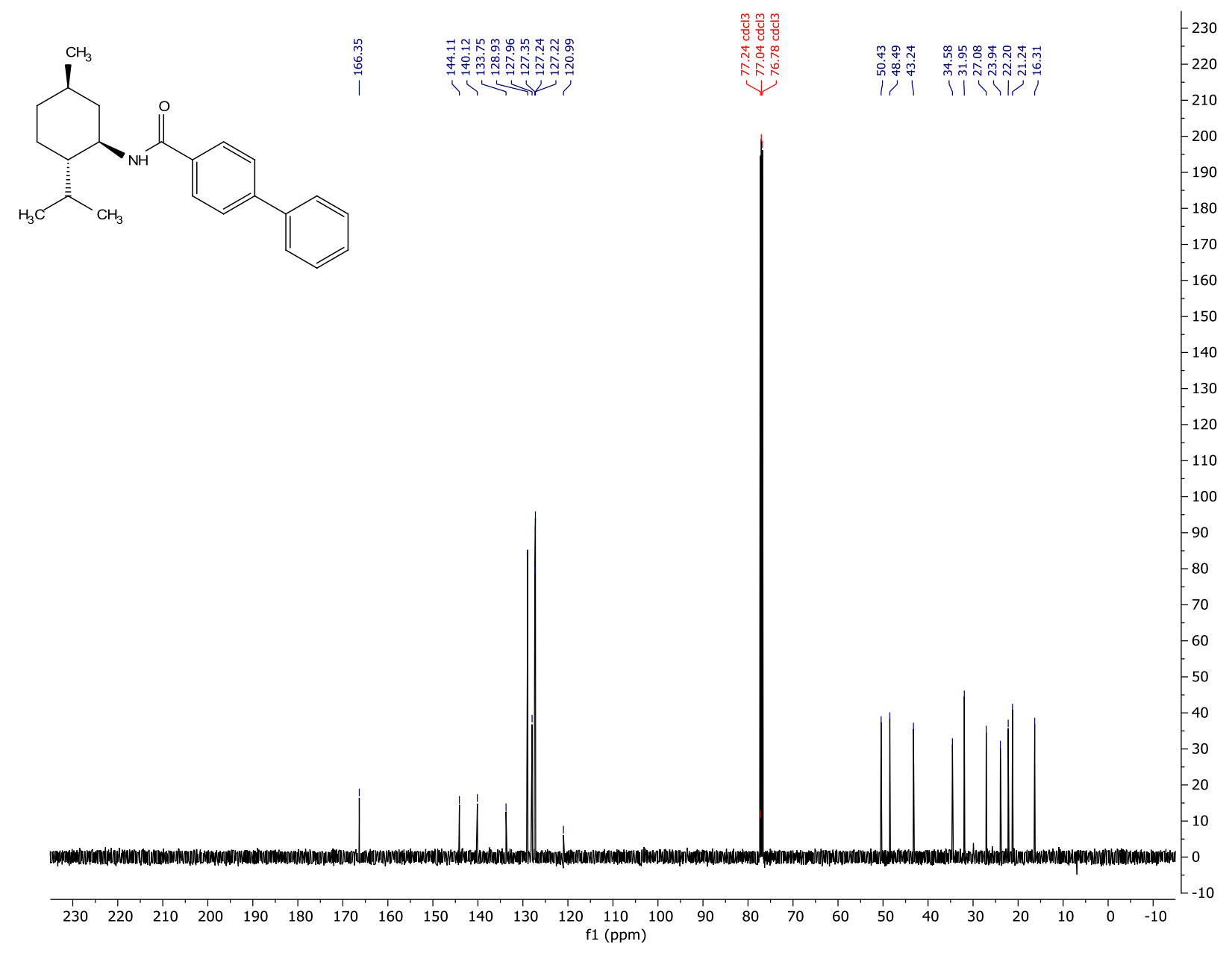

Figure S13. ${ }^{13} \mathrm{C}$ NMR (500 MHz) of $\mathrm{N}-((1 R, 2 S, 5 R)$-2-isopropyl-5-methylcyclohexyl)-[1,1'biphenyl]-4-carboxamide (1). 


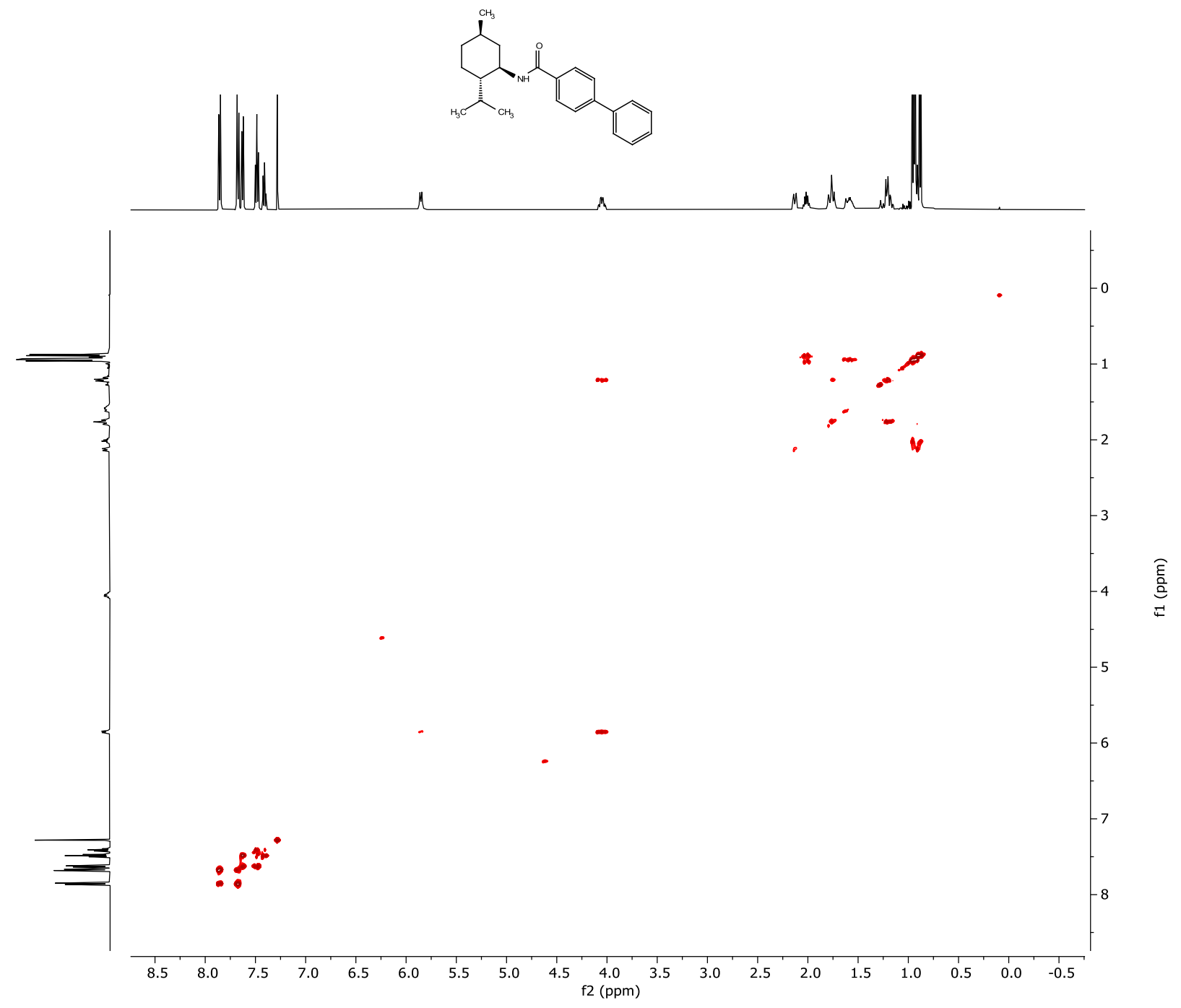

Figure S14. COSY (500 MHz) of $\mathrm{N}-((1 R, 2 S, 5 R)$-2-isopropyl-5-methylcyclohexyl)-[1,1'biphenyl]-4-carboxamide (1). 


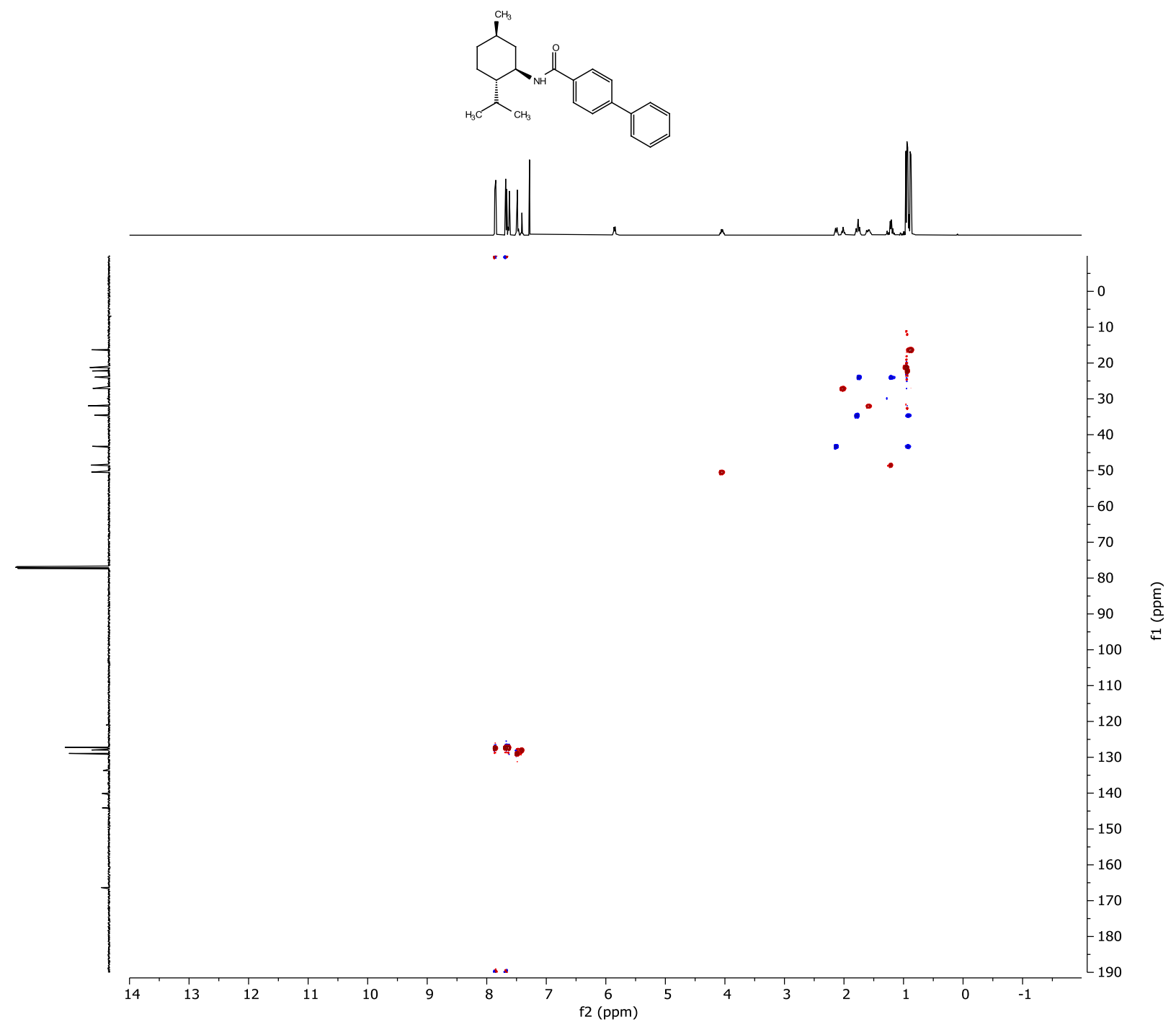

Figure S15. gHSQCAD (500 MHz) of N-((1R,2S,5R)-2-isopropyl-5-methylcyclohexyl)-[1,1'biphenyl]-4-carboxamide (1). 


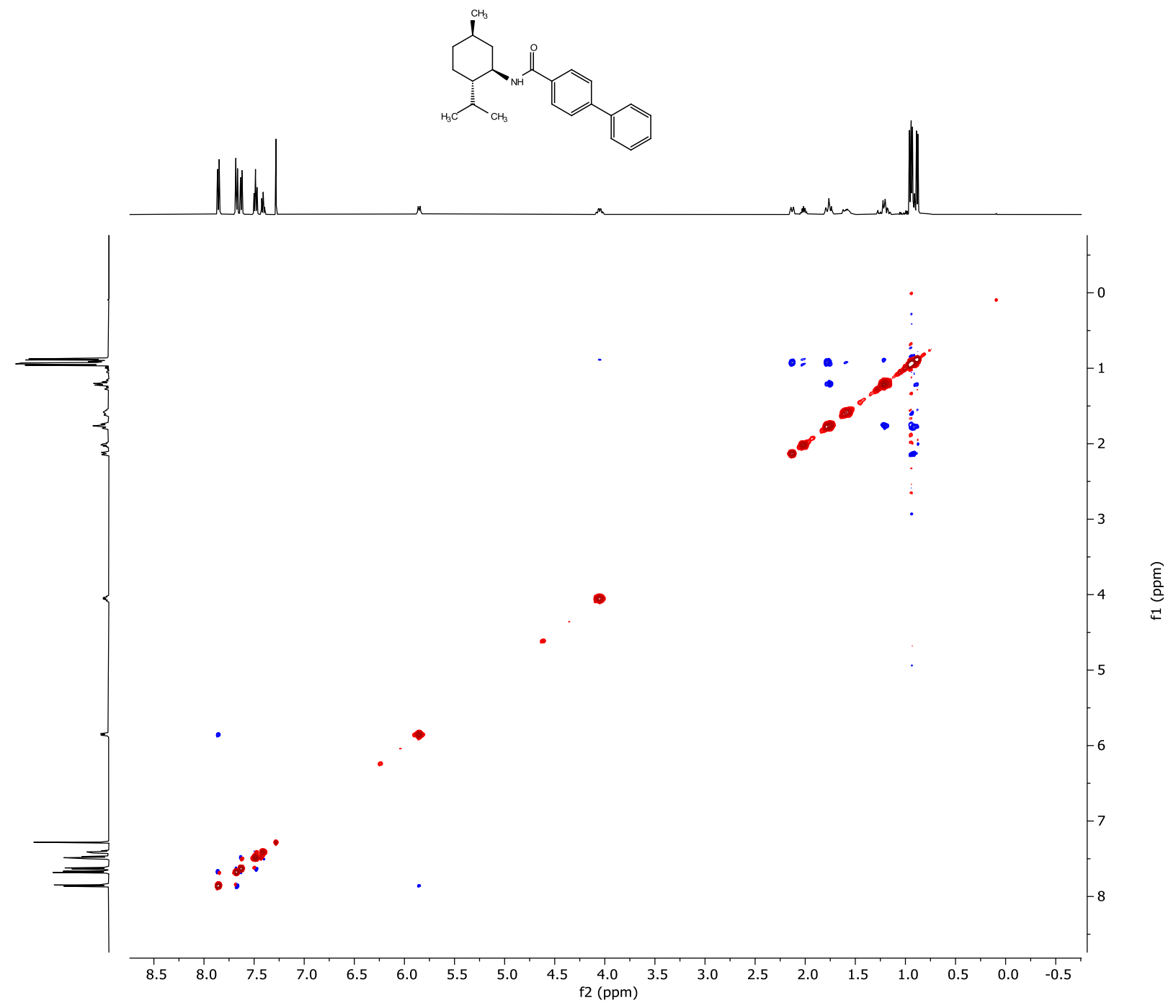

Figure S16. NOESY (500 MHz) of $\mathrm{N}-((1 R, 2 S, 5 R)$-2-isopropyl-5-methylcyclohexyl)-[1,1'biphenyl]-4-carboxamide (1). 


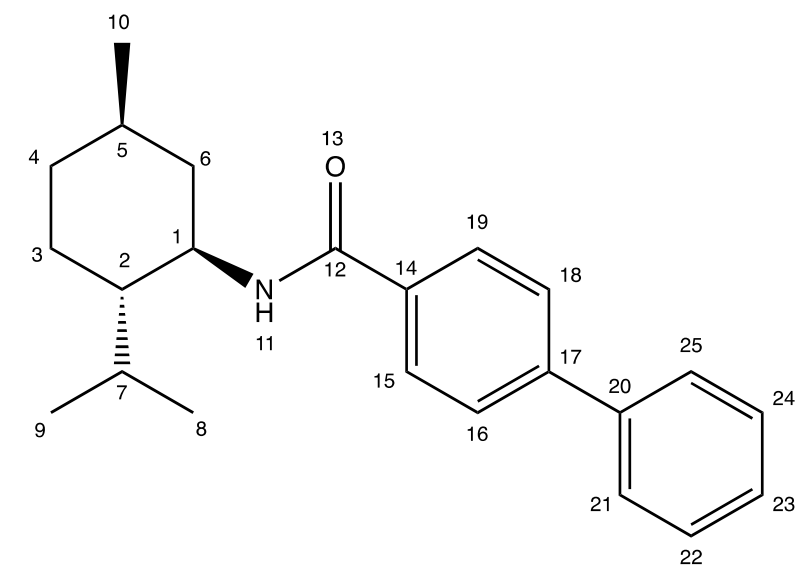

Table S1. ${ }^{1} \mathrm{H}$ and ${ }^{13} \mathrm{C}$ NMR assignments of (-)-menthyl 1.

\begin{tabular}{ccc}
\hline Atom & ${ }^{1} \mathrm{H}(\mathrm{ppm})$ & ${ }^{13} \mathrm{C}(\mathrm{ppm})$ \\
1 & $\mathrm{H} 1: 4.05(\mathrm{ddd}, J=11.3,11.3,9.8,3.5 \mathrm{~Hz}, 1 \mathrm{H})$ & 50.4 \\
2 & $1.21(\mathrm{~m}, 1 \mathrm{H})$ & 48.5 \\
3 & $\mathrm{H} 3: 1.26(\mathrm{~m}, 1 \mathrm{H}), \mathrm{H} 3 ': 1.76(\mathrm{~m}, 1 \mathrm{H})$ & 24.0 \\
4 & $\mathrm{H} 4: 0.91(\mathrm{~m}, 1 \mathrm{H}), \mathrm{H} 4{ }^{\prime}: 1.78(\mathrm{~m}, 1 \mathrm{H})$ & 34.6 \\
5 & $\mathrm{H} 5: 1.58(\mathrm{~m}, 1 \mathrm{H})$ & 32.0 \\
6 & $\mathrm{H} 6: 2.13(\mathrm{dtd}, J=12.3,3.8,3.7,2.0 \mathrm{~Hz}, 1 \mathrm{H}), \mathrm{H} 66^{\prime}: 0.92(\mathrm{~m}, 1 \mathrm{H})$ & 43.2 \\
7 & $\mathrm{H} 7: 2.00(\mathrm{pd}, J=7.0,7.0,7.0,7.0,2.1 \mathrm{~Hz}, 1 \mathrm{H})$ & 27.1 \\
8 & $\mathrm{H} 8: 0.88(\mathrm{~d}, J=6.9 \mathrm{~Hz}, 1 \mathrm{H})$ & 16.3 \\
9 & $\mathrm{H} 9: 0.95(\mathrm{~d}, J=7.0 \mathrm{~Hz}, 1 \mathrm{H})$ & 21.2 \\
10 & $\mathrm{H} 10: 0.94(\mathrm{~d}, J=6.7 \mathrm{~Hz}, 1 \mathrm{H})$ & 22.2 \\
11 & $5.85(\mathrm{brd}, J=9.4 \mathrm{~Hz}, 1 \mathrm{H})$ & -- \\
12 & --- & 166.4 \\
13 & --- & --- \\
14 & --- & 133.8 \\
15,19 & $\mathrm{H} 15,19: 7.86(\mathrm{~d}, J=8.4 \mathrm{~Hz}, 2 \mathrm{H})$ & 127.4 \\
16,18 & $\mathrm{H} 16,18: 7.67(\mathrm{t}, J=8.3 \mathrm{~Hz}, 2 \mathrm{H})$ & 144.1 \\
17 & --- & 140.1 \\
20 & --- & 127.35 \\
21,25 & $\mathrm{H} 21,25: 7.63(\mathrm{~d}, J=8.1 \mathrm{~Hz}, 2 \mathrm{H})$ & 128.9 \\
22,24 & $\mathrm{H} 22,24: 7.49(\mathrm{t}, J=7.5 \mathrm{~Hz}, 2 \mathrm{H})$ & \\
23 & $\mathrm{H} 23: 7.39(\mathrm{t}, \mathrm{J}=7.4 \mathrm{~Hz}, 1 \mathrm{H})$ & \\
\hline
\end{tabular}

Stereochemistry was determined based on the large coupling constants to $\mathrm{H} 1(11.3 \mathrm{~Hz})$, which can only occur when protons $\mathrm{H} 6$ and $\mathrm{H} 2$ are trans to $\mathrm{H} 1$. Additional evidence was obtained from NOESY data showing NOE interactions from the NH proton to H6 and H2 (Figure 3). Finally, 
comparison to literature NMR data of the compound confirmed the relative stereochemistry (see compound 1d NMR data in supplementary data). ${ }^{6}$

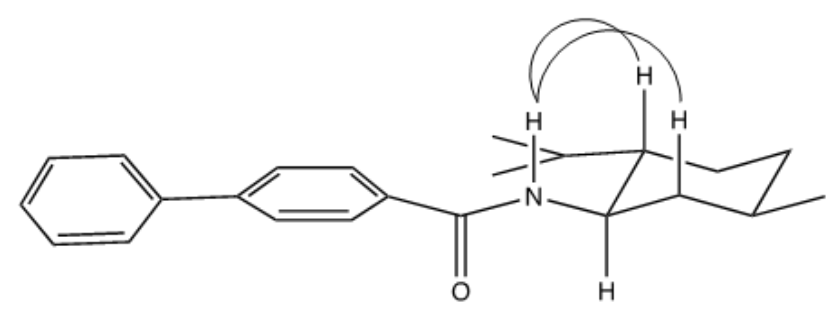

Figure S17. Key NOE interactions of (-)-menthyl 1 demonstrating relative configuration

\section{References}

(1) Kulisch, J.; Nieger, M.; Stecker, F.; Fischer, A.; Waldvogel, S. R. Efficient and stereodivergent electrochemical synthesis of optically pure menthylamines. Angew. Chem. Int. Ed. Engl. 2011, 50, 5564-5567.

(2) Rath, P.; Hilton, J. K.; Sisco, N. J.; Van Horn, W. D. Implications of Human Transient Receptor Potential Melastatin 8 (TRPM8) Channel Gating from Menthol Binding Studies of the Sensing Domain. Biochemistry 2016, 55, 114-124.

(3) Hilton, J. K.; Salehpour, T.; Sisco, N. J.; Rath, P.; Van Horn, W. D. Phosphoinositideinteracting regulator of TRP (PIRT) has opposing effects on human and mouse TRPM8 ion channels. J. Biol. Chem. 2018, 293, 9423-9434.

(4) Journigan, V. B.; Feng, Z.; Rahman, S.; Wang, Y.; Amin, A.; Heffner, C. E.; Bachtel, N.; Wang, S.; Gonzalez-Rodriguez, S.; Fernandez-Carvajal, A.; Fernandez-Ballester, G.; Hilton, J. K.; Van Horn, W. D.; Ferrer-Montiel, A.; Xie, X. Q.; Rahman, T. Structure-Based Design of Novel Biphenyl Amide Antagonists of Human Transient Receptor Potential Cation Channel Subfamily M Member 8 Channels with Potential Implications in the Treatment of Sensory Neuropathies. ACS Chem. Neurosci. 2020, 11, 268-290.

(5) Yin, Y.; Wu, M.; Zubcevic, L.; Borschel, W. F.; Lander, G. C.; Lee, S. Y. Structure of the cold- and menthol-sensing ion channel TRPM8. Science 2018, 359, 237-241.

(6) Ortar, G.; De Petrocellis, L.; Morera, L.; Moriello, A. S.; Orlando, P.; Morera, E.; Nalli, M.; Di Marzo, V. (-)-Menthylamine derivatives as potent and selective antagonists of transient receptor potential melastatin type-8 (TRPM8) channels. Bioorg. Med. Chem. Lett. 2010, 20, 27292732. 